\title{
Bacterial Cellulose Production in The Overripe Guava Juice by Acetobacter xylinum as A Solution to Reduce Organic Waste
}

\author{
Annisa Nur Lathifaha, *, Isa Nuryana ${ }^{\text {b }}$ \\ ${ }^{a}$ Department of Environmental Engineering, Faculty of Civil Engineering and Planning, \\ Universitas Islam Indonesia \\ Jl. Kaliurang Km 14,5, Yogyakarta, 55584, Indonesia \\ ${ }^{b}$ Research Center for Biotechnology, Indonesian Institute of Sciences \\ Jl. Raya Bogor KM 46, Cibinong, Bogor 16911, West Java, Indonesia \\ *Corresponding Author. Tel: (0274)-896440 ext:3210; Fax: (0274) 895330 \\ E-mail: annisa.lathifah@uii.ac.id
}

\begin{tabular}{|c|c|}
\hline ARTICLE INFO & ABSTRACT \\
\hline $\begin{array}{l}\text { Article History: } \\
\text { Received date: } 16 \text { June } 2021 \\
\text { Revised date: } 16 \text { July } 2021 \\
\text { Accepted date: } 27 \text { July } 2021 \\
\text { Available online at: November } 2021\end{array}$ & \multirow{2}{*}{$\begin{array}{l}\text { The exploration of a new cost-effective c arbon source with a } \\
\text { time-saving fermentation process for obtaining the high yield of } \\
\text { product is currently getting more attention. This research aims to } \\
\text { study the use of overripe guava as an inexpensive carbon source } \\
\text { to produce bacterial cellulose (BC), namely Nata de guava, by } \\
\text { employing Acetobacter xylinum. The overripe guava was prepared } \\
\text { for fermentation medium by extracting the fruit in distilled water } \\
\text { with various concentrations. The result indicated that bacterial } \\
\text { cellulose started to arise on the surface of the medium after two days } \\
\text { of incubation. The thickest BC product ( } 1.27 \text { cm) was achieved from } \\
\text { the media containing } 23 \mathrm{~g} / \mathrm{L} \text { of reducing sugar (substrate } 100 \% \text { ) } \\
\text { at pH } 4 \text {. Furthermore, this study showed that BC could be formed } \\
\text { without the addition of carbon and nitrogen from external sources } \\
\text { due to the high contents of reducing sugar and protein in the overripe } \\
\text { guava medium. Considering the abundant resource of the overripe } \\
\text { guava fruit waste in Java, the present study attempts to develop an } \\
\text { alternative methodology to synthesize BC. Most importantly, this } \\
\text { study provides a new insight to manage organic waste specifically } \\
\text { from overripe guava fruit. } \\
\text { C) } 2021 \text { Jurnal Kimia Terapan Indonesia. This is an open access article } \\
\text { under the CC BY-NC-SA license (https://creativecommons.org/licenses/ } \\
\text { by-nc-sa/4.0/). }\end{array}$} \\
\hline $\begin{array}{l}\text { Keywords: } \\
\text { Keywords: bacterial cellulose, Ace- } \\
\text { tobacter xylinum, overripe guava, } \\
\text { organic waste }\end{array}$ & \\
\hline
\end{tabular}

\section{INTRODUCTION}

Indonesia, as a tropical country, can produce a variety of fruits including guava (Psidium guajava L.). Due to its climacteric nature, Guava is one of the horticulture products that is easily damaged mechanically, chemically and microbiologically [1][2]. During the transportation and sale process, guava fruit will experience ripening, leading to the aging process (senescence). As a result, the fruit will become overripe so it can decrease the selling point [3] and potentially become organic waste. Based on data from the Central Bureau of Statistic [4], the amount of guava fruit production on the island of Java was quite high in the last two years, in the amount of 170,339 tons in 2019 and 287.570 tons in 2020. Thus, it is possible that the island of Java produced a high amount of guava fruit waste.

In fact, overripe guava still contains reducing sugar, acid and nutrients. The reducing sugar 
content in the overripe guava is about 6\% [5][2]. Thus, it is potential substrate for nata production, which requires reducing sugar by $2-10 \%$ [6][7]. Nata is a white, insoluble, gelatin-like solid, which is a thin layer of cells and polysaccharides, namely bacterial cellulose (BC) formed by Acetobacter xylinum [6], the most efficient bacterial cellulose producer [8]. During the fermentation process, A. xylinum converts glucose into a layer of extracellular cellulose, which releases and gradually covers the surface [9]. Later on, the nata is called nata de guava. In addition, the high reducing sugar content in the overripe guava allows no addition of sugar in the fermentation process.

Nowadays, the production of bacterial cellulose or nata is increasing, since it can be used as a reinforcement of high-quality papers, textile, electronic display and audio membranes [10-14]. However, high cost and low-yield production have limited the industrial production of $\mathrm{BC}$ and its commercial application [15]. Therefore, the exploration for a new cost-effective carbon source with a shorter fermentation process for high yield $\mathrm{BC}$ production is still needed. The study by Aulia et al. [16] utilizes fresh red guava juice for making BC. This research uses additional sugar (as carbon source) and $\mathrm{Za}$ (as nitrogen source) in the $\mathrm{BC}$ production. However, research on making $\mathrm{BC}$ from overripe guava and without the addition of carbon and nitrogen sources has not yet been reported. On the other hand, the study by Syamsiah and Gunawan [17] utilizes fruit waste for biogas production. However, before it is actually made into biogas, the juice can be extracted for making BC. Therefore, the purpose of this study is to utilize overripe guava fruit as an alternative substrate for bacterial cellulose (BC) production by Acetobacter xylinum. The results obtained from the study provide insight into the solution to reduce the amount of organic waste, especially fruit waste and the optimal utilization of food resources.

\section{EXPERIMENTAL SECTION}

\subsection{Material}

This study used overripe red guava fruit from the species Psidium guajava L., Bangkok variety, obtained from Gamping fruit market, Sleman. This is an overripe guava fruit, yellow to brown in color, where the skin of the fruit tears and collapses easily. The juice of the fruit was used as a substrate of $A$. xylinum in making bacterial cellulose (BC) or nata. The inoculum of $A$. xylinum used in this study was purchased from CV. Agroprima industry, Sedayu, Bantul, Yogyakarta. The chemicals used in this study were 3,5-Dinitrosalicylic acid (DNS) reagent, $0.1 \mathrm{~N}$ $\mathrm{NaOH}$, distilled water, neutral distilled water, Bromothymol blue (BTB) indicator, potassium carbonate, potassium dichromate, anhydrous glucose and vaseline.

\subsection{Instrumentation}

The tools used in this study were a bottle jar with the same diameter of $6 \mathrm{~cm}$ and the same height for the growth of A. xylinum (Figure S1.), autoclave (Harvard / LTE) for sterilizing overripe guava juice, UV-VIS spectrophotometer for reducing sugar analysis, a Conway diffusion dish for alcohol content analysis and glassware.

\subsection{Methods}

\subsubsection{Inoculum preparation}

The inoculum of A. xylinum was prepared using Schramm-Hestrin ( $\mathrm{SH}$ ) and Peptone Glucose Yeast Extract (PGY) medium. Schramm-Hestrin (SH) medium contains $20 \mathrm{~g}$ glucose per liter, $5 \mathrm{~g}$ peptone, $5 \mathrm{~g}$ yeast extract, $2.7 \mathrm{~g}$ anhydrous disodium phosphate and $1.5 \mathrm{~g}$ citric acid monohydrate. $1.5 \%$ agar is added for the solid $\mathrm{SH}$ medium, while the characteristics of $A$. xylinum were confirmed using glucose and sucrose medium.

\subsubsection{Substrate preparation}

The overripe guava fruits were mashed using a blender with the addition of distilled water in the ratio of 1:1, 1:2, 1:3 and 1:4. Next, it was filtered using a filter cloth to obtain only the juice without pulp, which resulted in overripe guava juice at different concentrations, e.g. 100\%, 75\%, $50 \%$ and $25 \%$. These were used as treatment in this study, namely substrate $100 \%$ (reactor A1), substrate $75 \%$ (reactor A2), substrate $50 \%$ (reactor A3) and substrate 25\% (reactor A4) (Fig. S1). 
The filtrates will be used as growth medium for A. xylinum without the addition of both carbon and nitrogen from external sources. A total of 100 $\mathrm{ml}$ overripe guava filtrate juice from each treatment was placed into a $250 \mathrm{ml}$ glass bottle with a diameter of approximately $6 \mathrm{~cm}$ and a height of $12 \mathrm{~cm}$. The bottles were covered with parchment paper then tied with rubber, then sterilized by autoclaving at $121^{\circ} \mathrm{C}$ for 15 minutes.

\subsubsection{Fermentation}

Fermentations were performed under static conditions (batch culture). Briefly, a total of 20 $\mathrm{ml}$ of inoculum (which contains $1 \times 10^{7} \mathrm{cell} / \mathrm{ml}$ ) was inoculated into the $100 \mathrm{ml}$ sterilized filtrate juice. The experiments were performed in triplicate for each treatment. Samples were collected at regular intervals (every 2 days) for 2 weeks of fermentation to observe A. xylinum growth, substrate consumption (reducing sugar content), bacterial cellulose production (the rate formation of nata), the $\mathrm{pH}$ value, the alcohol and total acid concentration.

\subsubsection{The A. xylinum growth analysis}

The A. xylinum growth was analyzed using the Total Plate Count (TPC) method, refer to Cappucino and Sherman [18]. Briefly, a total of 1 $\mathrm{ml}$ of the sample was put into a test tube, where serial dilution was carried out until 10-7. A total of $1 \mathrm{ml}$ of the 10-5, 10-6 and 10-7 dilutions was taken and spread using a sterilized spreader in a petri dish containing Herstin- Schramm (HS) agar medium. Then it was incubated for 5 days in an incubator at $30^{\circ} \mathrm{C}$. From the number of colonies per petri dish, the number of bacteria per $\mathrm{ml}$ of material can be determined, namely by multiplying the number of colonies by the reciprocal of dilution. The calculation with TPC needs to pay attention to several calculation requirements that are needed referring to Cappucino and Sherman [18].

\subsubsection{Substrate consumption or reducing sugar content analysis}

The substrate consumption or reducing sugar content was determined by spectrophotometry using the 3,5-Dinitrosalicylic acid (DNS) method-- referred to [19]. Briefly, a total of $3 \mathrm{ml}$ DNS reagent was added to $1 \mathrm{ml}$ of sample in a test tube. A blank solution containing $1.0 \mathrm{ml}$ of distilled water and $3 \mathrm{ml}$ of DNS was run parallel. The tubes were heated in a boiling water bath for $15 \mathrm{~min}$. After cooling the tubes at room temperature, $8 \mathrm{ml}$ distilled water was added in each and absorbance was noted at $575 \mathrm{~nm}$. Reducing sugar concentration was determined from the standard curve of glucose and multiplied by dilution factor.

\subsubsection{Bacterial cellulose production analysis}

The bacterial cellulose production or the formation of nata was analyzed by measuring its thickness using vernier calipers.

\subsubsection{Alcohol content analysis}

The alcohol content was determined quantitatively using the Chamber Conway method-- refer to [20]. A Conway unit is used for alcohol detection by this procedure. Briefly, one $\mathrm{ml}$ potassium dichromate was placed into the Conway unit center and a sample was placed around the center. The Conway unit was then covered by a glass plate and incubated at $30^{\circ} \mathrm{C}$ for 2 hours for reaction. The water and alcohol slowly evaporated, came in contact with Potassium dichromate and then oxidized. More alcohol evaporated until eventually all the alcohol from the fermented dilute solution had left the sample and reacted with the dichromate. After 2 hours, a total of $0.5 \mathrm{ml}$ solution in the center of the Conway unit was taken and diluted with $4.5 \mathrm{ml}$ distilled water. Then, the solution was observed in a spectrophotometer with a wavelength $(\lambda)$ of $480 \mathrm{~nm}$, and as a blank was distilled water. One Conway unit was used as a blank and in that unit, $1 \mathrm{ml}$ distilled was used as a sample. The standard curve was prepared using standard alcohol at concentrations of 0.08, 0.06, 0.04 and $0.020 \mathrm{~g} / \mathrm{L}$.

\subsubsection{Total Acid content analysis}

The total acid concentration was determined using the titration method-- refer to [21]. Briefly, a total of $1 \mathrm{ml}$ of sample was taken and put into a $25 \mathrm{ml}$ Erlenmeyer, then $10 \mathrm{ml}$ of neutral distilled water and 3 drops of Bromothymol blue (BTB) indicator were added. Then it was titrated with 
$0.1 \mathrm{~N} \mathrm{NaOH}$ until the clear color changed to blue green. The total acid content in the sample is expressed as a percentage of acetic acid calculated by the formula:

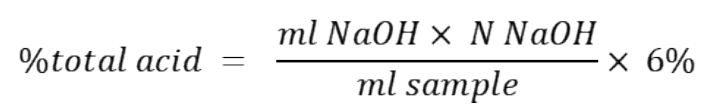

\subsection{9 pH analysis}

The $\mathrm{pH}$ of substrate during fermentation was analyzed using a $\mathrm{pH}$ meter.

\subsubsection{The nutritional content (proximate) analysis of red overripe guava.}

The proximate analysis of red overripe guava juice using in this study was conducted at the Food and Nutrition Laboratory, Universitas Gadjah Mada, Yogyakarta. The analysis included water content, protein, fat and ash.

\section{RESULTS AND DISCUSSION}

Growth parameters of A. xylinum in the overripe guava substrates were observed in the decrease in reducing sugar (Fig. 1), the rate formation of bacterial cellulose (BC) (Fig. 2) and the decrease in $\mathrm{pH}$ (Fig. 5). The alcohol concentration (Fig. 3 ) and the total acid concentration (Fig. 4) were also observed during the fermentation. The results showed that $A$. xylinum was able to grow on the medium containing overripe guava juice in different concentrations and produced $\mathrm{BC}$ or nata. It was later called nata de guava. The medium containing overripe guava juice with reducing sugar content $23 \mathrm{~g} / \mathrm{L}$ (substrate $100 \%$ ) at $\mathrm{pH} 4$ produced the thickest BC $(1.267 \mathrm{~cm})$ (Fig. 1) (Table S1). Thickness parameters can indicate the quality of $\mathrm{BC}$ production by A. xylinum. The thickness of the $\mathrm{BC}$ in each overripe guava substrate increased according to the growth pattern of A. xylinum (Fig. 1) and along with the increase of incubation time (Fig.2).

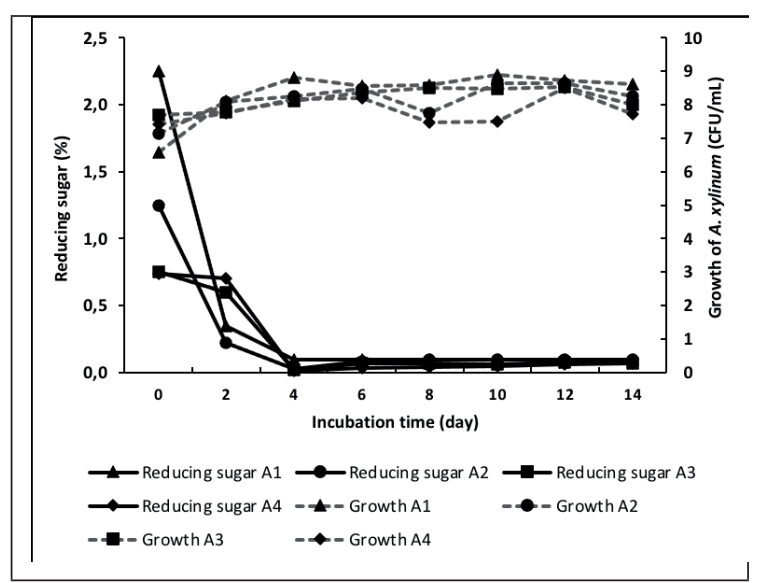

Fig. 1. The growth of A. xylinum in the different concentrations of overripe guava substrate during the $\mathrm{BC}$ or nata formation.

At the beginning of incubation, there was an accelerated growth of A. xylinum in all reactors, which was indicated by a sharply increasing curve (Fig. 1). The A. xylinum began to grow without a clear lag phase, indicating that the microorganism did not require a phase adjustment (lag phase) for replication in the carbon source containing the overripe guava juice. Such conditions can occur because in this study, the used inoculum is mature enough and meets the requirements to enter the exponential/log phase, which reached $1 \times 10^{7}$ cells $/ \mathrm{ml}$. Our results (Fig. 1) showed that in reactor $\mathrm{A} 3$, on day 2 , there was a decrease in sugar content, accompanied by an increase in the growth of $A$. xylinum and the formation of pellicle nata, which is the primary metabolite of A. xylinum. The growth and thickness of nata continued to increase until day 12 . In reactor A2 and A4, it continued to increase until day 6, while in reactor A1 until day 4. In this phase, $A$. xylinum has entered the exponential/log phase, the phase where reducing sugars that are the substrate for the growth of A. xylinum are used very well to produce energy to grow and convert glucose into cellulose (formation of nata) [22]. In reactor A2 and A4, the growth of A. xylinum decreased on day 8 , but slowly increased again until day 12 , while in reactor $\mathrm{A} 1$, it decreased on day 4 , but slowly increased again on day 8 until day 12. In this phase, the growth of A. xylinum did not increase drastically, but the thickness of the nata continued to increase. This condition occurred possibly because more energy was used to convert glucose into cellulose than to grow to 
increase biomass. In all reactors, from day 12 to day 14, the growth of $A$. xylinum and the thickness of nata did not increase. This means that $A$. xylinum has been in a stationary phase, namely the phase when nutrients are decreasing or are even depleted, where there is not enough dissolved oxygen available, and a lot of secondary metabolites have been formed, thereby inhibiting the growth of $A$. xylinum [22].

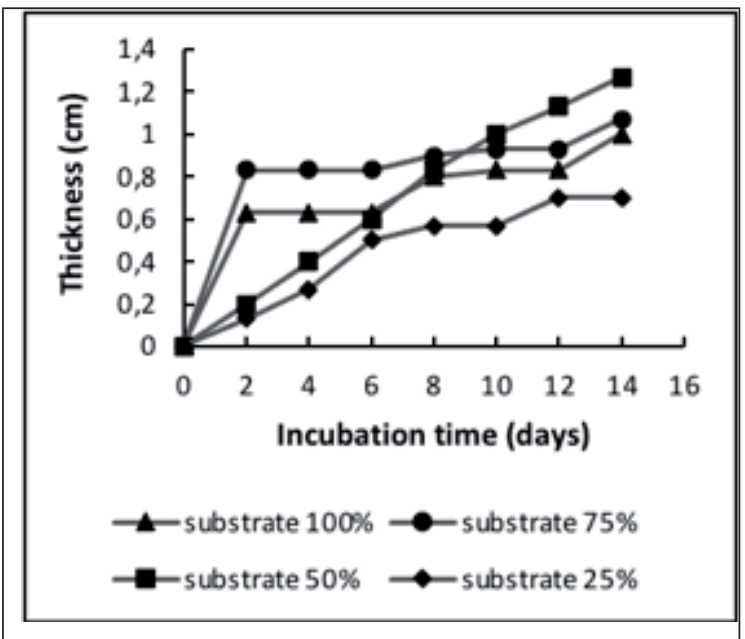

Fig. 2. The average velocity pattern of $\mathrm{BC}$ formation in the different concentrations of overripe guava substrate.

One of the important factors for the success of $\mathrm{BC}$ or nata formation is to maintain the growth of $A$. xylinum to grow on suitable media and produce cellulose. During the formation of BC, A. xylinum performs metabolic activities in obtaining energy, which include aerobic respiration (normal pathway) and alcoholic fermentation, which continues in acetic acid fermentation. The reducing sugar compound, in the form of glucose, in the media is used by A. xylinum as an energy source to carry out its metabolic activities. The bacteria will convert glucose into precursors (UDP-glucose) on the cell membrane, which is then excreted to the outside of the cell catalyzing by enzymes that polymerize glucose into cellulose [22]. Our results show that with the longer incubation time, there is additional decrease in reducing sugar content (nutrients in the substrate decreases) (Fig. 1; Fig. 2). This is due to the use of reducing sugars for growth (Fig. 1) and the conversion of glucose into cellulose (Fig. 2).

During the fermentation of $\mathrm{BC}$ or nata by $A$. xylinum, alcohol is synthesized. Our results show that the alcohol content produced by $A$. xylinum is relatively low $(0.2$ to $0.6 \%)$. During 14 days of observation, the resulting alcohol content is fluctuated. After 8 days of incubation, the alcohol content in all treatments dropped dramatically (Fig. 3). These indicate that the alcohol is further oxidized into acetic acid. This condition also explains why in reactors $\mathrm{A} 1, \mathrm{~A} 2$ and $\mathrm{A} 4$, there was a decrease in cell growth on days 6 and 8 . Under conditions of alcoholic fermentation to acetic acid, the energy produced in this process was less than in ordinary aerobic conditions [22]. Therefore, the energy produced is used to focus on survival on the media rather than to increase biomass. Then, from day 10 to day 14, there was an increase in alcohol levels. When the alcohol in the medium begins to decrease, the bacteria resynthesize the alcohol. The synthesis of alcohol by bacteria is carried out when the dissolved oxygen in the medium is in limited conditions. Under these conditions, aerobic $A$. xylinum bacteria cannot use glucose in the respiratory pathway to meet their energy needs, so these bacteria will choose the fermentation pathway so that they can continue to supply ATP energy even though the quantity will be smaller than if they do respiration [22].

The alcohol formed triggers the occurrence of alcoholic fermentation, where the alcohol will be oxidized to acetic acid. Alcohol fermentation is a pathway for bacteria to obtain energy through the pentose phosphate pathway [22]. The level of acid formed in this study is shown in Fig. 4. At the beginning of the incubation period, namely day 0 to day 4 , acid levels increased sharply, presumably due to the use of glucose for acid formation. This is reinforced by the data shown in Fig. 1; the reducing sugar content from day 0 to day 4 decreased drastically. Meanwhile on that day, the nata formed at the substrate containing reducing sugar of $45 \mathrm{~g} / \mathrm{L}$ and $30 \mathrm{~g} / \mathrm{L}$ was still thin, while the substrate containing reducing sugar of $23 \mathrm{~g} / \mathrm{L}$ and $20 \mathrm{~g} / \mathrm{L}$, nata was not yet formed (Fig. 2 ). This suggested that the formation of acid from glucose intends to get more energy used for cell growth than the formation of BC. From the results of the oxidation/respiration of glucose, the energy obtained is 36 ATP [22]. Bacteria need this large energy, because at the beginning of incubation, 
bacterial growth is in a logarithmic phase (Fig. 1). At the end of the incubation period, namely days 10 to 14 , acid levels tend to decrease. This is presumably because at the end of the incubation period, the reducing sugar content was almost gone.

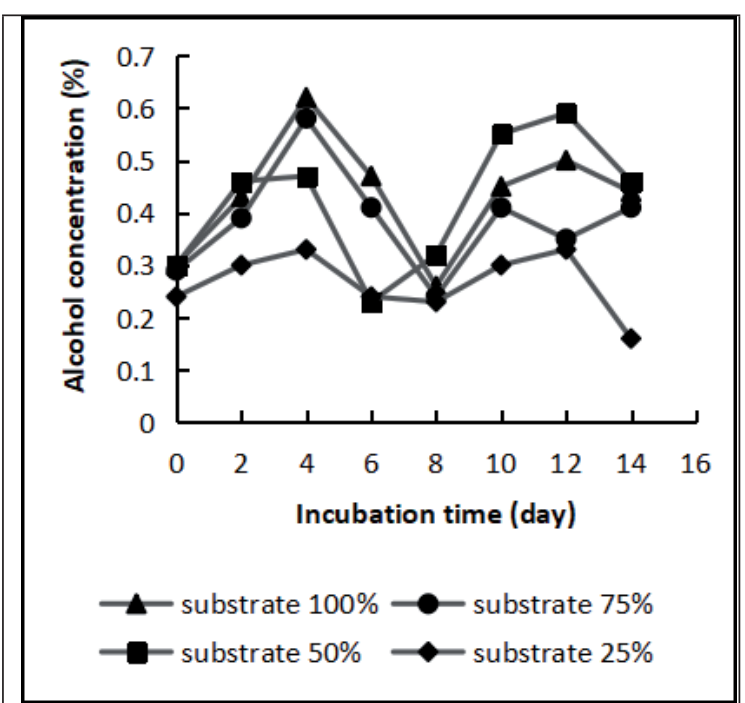

Fig. 3. The alcohol concentration during the $\mathrm{BC}$ fermentation in the different concentrations of overripe guava substrate.

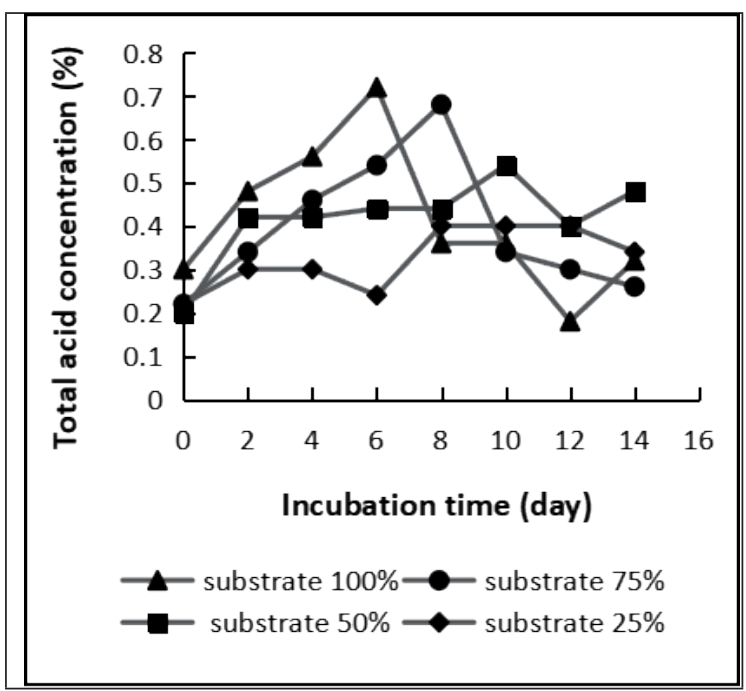

Fig. 4. The total acid concentration during the $\mathrm{BC}$ fermentation in the different concentrations of overripe guava substrate.

The presence of acid formed during cultivation also plays a role in maintaining the stability of the $\mathrm{pH}$ of the medium so that the cultivation can take place optimally. Low acidity can maintain the environmental conditions of the medium to avoid contaminants in the form of fungi, yeasts and other bacteria that can interfere with the activity of A. xylinum in producing cellulose. According to [7][3], the required $\mathrm{pH}$ in making nata is $3-5$ or in an acidic environment. The $\mathrm{pH}$ conditions during the incubation time (Fig. 5) showed that during fermentation, the $\mathrm{pH}$ of the medium was maintained at 3-5, an acidic environment.

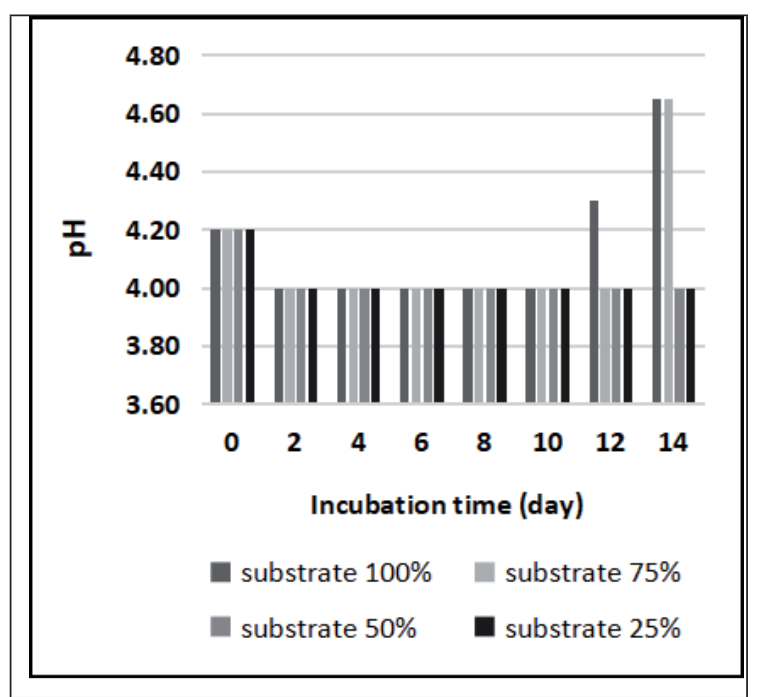

Fig. 5. The change of $\mathrm{pH}$ value during the $\mathrm{BC}$ formation in the different concentrations of overripe guava substrate.

There have been many reports about cellulose being produced by $A$. xylinum from different kinds of substrates such as coconut water [23], papaya [24], tobacco waste [25] and coconut shell hydrolysate [26]. However, to our knowledge, the production from overripe guava has not yet been reported. Meanwhile there is a study by Setiani et al. [27] which reported the production of nata de guava. However, the study used different species of guava compared to our study, namely Syzygium samarangense. In that study, the addition of carbon source from sucrose and nitrogen source from bean sprouts extract with levels up to $15 \%$ is still needed. Meanwhile, our study showed that without the addition of carbon and nitrogen sources, nata could be formed. On the other hand, a study by Aulia et al. [16] and Mardhatillah [28] reported the production of nata de guava, yet the substrate used was not overripe guava. Furthermore, when comparing the thickness of the formed nata, the thickness of the nata produced in that study was $0.98 \mathrm{~cm}$, thinner than the thickness of the nata produced in our study, which was $1.27 \mathrm{~cm}$. The results of the proximate analysis showed that the total sugar 
and protein content of the overripe guava used in this study was equal to $4.5 \%$ and $0.9 \%$, respectively (Table S2). Thus, nitrogen and carbon from other sources are not needed. This could be one of the advantages of using overripe guava as a substrate for making BC or nata, because there is no additional cost for carbon and nitrogen from external sources.

Bacterial cellulose (BC) has certain better characteristics for most uses than cellulose from plants. BC has higher degrees of purity, tensile strength, porosity, water-holding capacity, biodegradability and biological adaptability [29][30] [31][32]. However, the high production cost of $\mathrm{BC}$, especially due to the cost of fermentation medium, has become one of the challenges to its general application in industrial and academic fields. Recently, to answer the challenge, the exploration of alternative medium from various industrial by-products and agroforestry waste is still ongoing. Our results show that bacterial cellulose can be produced by the growth of $A$. xylinum in overripe guava substrate, which potentially becomes organic waste, without any addition of carbon and nitrogen from external source. Thus, our findings may corroborate those ongoing studies. Moreover, our results also give a new insight into managing organic waste, specifically from fruit rather than the waste being thrown away and becoming organic waste generation.

\section{CONCLUSION}

The overripe guava can be used as a promising substrate for Bacterial cellulose (BC) production by Acetobacter xylinum. The medium containing $23 \mathrm{~g} / \mathrm{L}$ of reducing sugar (substrate $100 \%$ ) was the most recommended to produce the best $\mathrm{BC}$ with the following characteristics: gave the thickest BC $(1.27 \mathrm{~cm})$, high reducing sugar content, high protein content, which causes no need for additional nitrogen, stable $\mathrm{pH}$. Instead of being disposed of as waste, the overripe guava has the potential to be low-cost feedstock for BC production. Thus, the use of overripe guava can be considered as an alternative solution in reducing organic waste from fruits and supporting the concept of eco-friendly technology.

\section{REFERENCES}

[1] A. Mamede, H. Barboza, A. G. Soares, and A. C. V. Neves. "Postharvest physiology and technology for fresh guavas", In book: Tropical Fruits - From Cultivation to Consumption and Health Benefits - Guava and Mango, Edition: 1, Chapter: 6, Editors: S. Dimitrov Todorov and C. Stewart Bogsan, New York: Nova Science Publishers, 2016, pp. 91-108.

[2] Aparna, Dube and P. Singh, "Compositional evaluation of guava (Psidium guajava L.) cv. L-49 during fruit growth and development", Journal of Pharmacognosy and Phytochemistry, vol. 8 no. 5, 2019, pp. 68-71.

[3] M. P. Doyle, L. R. Beuchat, and T. J. Montville, Food Microbiology Fundamentals and Frontiers $2^{\text {nd }}$ ed, Washington D.C: American Society for Microbiology, 2001, p.131.

[4] Badan Pusat Statistik, Produksi tanaman buahbuahan 2019, 2019, Retrieved from https://www. bps.go.id/indicator/55/62/2/produksi-tanamanbuah-buahan.html/

[5] H. A. Bashir and A.B. A. Abu-Goukh. "Compositional changes during guava fruit ripening". Food Chemistry, vol. 80, 2003, pp. 557-563 DOI:10.1016/s0308-8146(02)00345-x.

[6] M.M. Lapuz, E.G. Gollardo, and Palo, M.A, "The Nata Organism Cultural Requirements Characteristic and Identity", The Philliphine Journal Science, vol. 96, 1967, pp. 91-109.

[7] A. K. Budiyanto, Mikrobiologi Terapan, Penerbit: Universitas Muhammadiyah Malang, 2002.

[8] H. El-Saied, A.H. Basta, and R.H. Gobran, "Research Progress in Friendly Environmental Technology for the Production of Cellulose Products (Bacterial Cellulose and Its Application)", Polymer-Plastics Technology and Engineering, vol. 43 no.3, 2004, pp.797-820 DOI: http://dx.doi.org/10.1081/PPT-120038065.

[9] G. E. Zipora, and Shlomo Hestrin, "Synthesis of Cellulose by Acetobacter xylinum", Journal Bacteriology, vol. 85, 1963, pp. 284-292 DOI: https://doi.org/10.1128/jb.85.2.284-292.1963.

[10] J. Shah, R. M. Brown, "Towards electronic paper displays made from microbial cellulose", Appl Microbiol Biotechnol, vol. 66, 2005, pp. 352-355 DOI: 10.1007/s00253-004-1756-6

[11] S. M. Santos, J. M. Carbajo, E. Quintana, D. Ibarra, N. Gomez, M. Ladero, M. E. Eugenio, and J. C. Villar, "Characterization of Purified Bacterial Cellulose Focused on Its Use on Paper Restoration", Carbohydrate Polymers, vol. 116,2015 , pp. 173-81 DOI: $10.1016 /$ j. carbpol.2014.03.064. 
[12] O. Singh, P. S. Panesar, and H. K. Chopra, "Response surface optimization for cellulose production from agro industrial waste by using new bacterial isolate Gluconacetobacter xylinus C18", Food Sci. Biotechnol., 26, 2017, pp. 1019-1028.

[13] Z. Li, L. Wang, J. Hua, S. Jia, J. Zhang, and H. Liu, "Production of nano bacterial cellulose from waste water of candied jujube processing industry using Acetobacter xylinum", Carbohydr. Polym., 120, 2015, pp. 115-119.

[14] J. H. Ha, O. Shehzad, S. Khan, S. Y. Lee, J. W. Park, T. Khan, and J. K. Park, "Production of bacterial cellulose by a static cultivation using the waste from beer culture broth", Korean J. Chem. Eng., 25, 2008, pp. 812-815.

[15] S. Q. Hu, Y. G. Gao, K. Tajima, N. Sunagawa, Y. Zhou, S. Kawano, T. Fujiwara, T. Yoda, D. Shimura, Y. Satoh, M. Munekata, I. Tanaka, and M. Yao, "Structure of bacterial cellulose synthase subunit D octamer with four inner passageways", Proc. Natl. Acad. Sci. U.S.A. vol.107, 2010, 17957-17961 DOI: 10.1073/ pnas. 1000601107

[16] N. Aulia, N. Nurwantoro, and S. Susanti, "Pengaruh Periode Fermentasi terhadap Karakteristik Fisik, Kimia dan Hedonik Nata Sari Jambu Biji Merah," Jurnal Teknologi Pangan, vol. 4, no. 1, 2020, pp. 36-41 DOI: https://doi.org/10.14710/ jtp.4.1.36-41.

[17] S. Syamsiah dan Gunawan, "Perancangan digester untuk mengolah limbah buah sebagai energi alternatif (biogas) dengan kapasitas 4 ton per hari: Studi evaluasi pemanfaatan limbah buah di Pasar Buah Gamping Sleman Yogyakarta”, Thesis: Universitas Gadjah Mada, 2014.

[18] J. G. Cappuccino and N. Sherman, Microbiology a Laboratory Manual 6th ed, San Fransisco: Benjamin Cummings, 2002, pp. 119-124.

[19] A. Jain, R. Jain, and S. Jain. "Quantitative Analysis of Reducing Sugars by 3, 5-Dinitrosalicylic Acid (DNSA Method)". In: Basic Techniques in Biochemistry, Microbiology and Molecular Biology. New York: Springer Protocols Handbooks, 2020. DOI: https://doi. org/10.1007/978-1-4939-9861-6_43.

[20] E. J. Conway, Microdiffusion Analysis and Volumetric Error, London: Crosby Lockwood and Son, 1939, pp. xiii +306.

[21] T. David and Plummer, An Introduction to Practical Biochemistry. London: McGraw-Hill Book Company, 1971, pp. 49-50.

[22] A. G. Moat and J.W. Foster, Microbial Physiology Third ed. John Wiley and Sons, Inc Publication, 1995, pp: 277-278.
[23] A. N. Darmawan and P. Aji, "Characterization of Nata de Coco Produced by Fermentation of Immobilized Acetobacter xylinum", Agriculture and Agricultural Science Procedia, vol. 3, 2015, pp. 278-282 DOI: https://doi.org/10.1016/j. aaspro.2015.01.053.

[24] K. A. Zahan, M. S. A. Hedzir, and M. Mustapha, "The Potential Use of Papaya Juice as Fermentation Medium for Bacterial Cellulose Production by Acetobacter xylinum 0416", Pertanika Journal of Tropical Agricultural Science, 40, 2017, pp. 343-350

[25] J. Ye, S. Zheng, Z. Zhang, F. Yang, K. Ma, Y. Feng, J. Zheng, D. Mao, X. Yang, "Bacterial cellulose production by Acetobacter xylinum ATCC 23767 using tobacco waste extract as culture medium", Bioresource Technology, vol. 274, 2019, pp. 518-524 DOI: https://doi. org/10.1016/j.biortech.2018.12.028.

[26] Y. Liu, F. Wang, and Y. Sun, "Bacterial cellulose production by Acetobacter xylinum using coconut shell acid hydrolysate as carbon source", BioResources, vol. 16, 2021, pp. 1042-1062 DOI:10.15376/biores.16.1.1042-1062.

[27] B E Setiani et al, "The characteristics of nata de guava (Syzygium samarangense) with certain interaction on the proportion of sprout extract (Phaseolus vulgaris) and sucrose", IOP Conf. Ser.: Earth Environ. Sci, 292, 2019.

[28] Mardhatillah, Perbandingan Jumlah Starter dan Lama Fermentasi Terhadap Karakteristik Nata de Guava, Diploma thesis, Universitas Andalas, 2020.

[29] S. Yamanaka, K. Watanabe, N. Kitamura, M. Iguchi, S. Mitsuhasi, Y. Nishi, et al., "The structure and mechanical properties of sheets prepared from bacterial cellulose", Journal of Materials Science, vol. 24, 1989, pp. 3141-3145 DOI:10.1007/BF01139032.

[30] C. Castro, R. Zuluaga, J. L. Putaux, G. Caro, I. Mondragon, and P. Gan án, "Structural characterization of bacterial cellulose produced by Gluconacetobacter swingsii sp. from Colombian agroindustrial wastes", Carbohydrate Polymers, vol. 84, 2011, pp. 96-102 DOI: https://doi. org/10.1016/j.carbpol.2010.10.072.

[31] C. Campano, A. Balea, A. Blanco, and C. Negro,"Enhancement of the fermentation process and properties of bacterial cellulose: a review", Cellulose, vol.23, 2016, pp. 57-91 DOI: https:// doi.org/10.1007/s10570-015-0802-0.

[32] S. Wang, F. Jiang, X. Xu, Y. Kuang, K. Fu, E. Hitz, and L. Hu, "Super-strong, super-stiff macro fibers with aligned, long bacterial cellulose", Nanofibers Adv. Mater, vol. 29, 2019, pp. 1702498 DOI: 10.1002/adma.201702498. 